\title{
Nalini Arles
}

\section{THE CHURCH'S RESPONSE TO THE HIV/AIDS EPIDEMIC IN INDIA}

\begin{abstract}
I gratefully remember working with Reverend Charles in a rehabilitation centre in the US and later with my HIV-positive friends in India. Their laughter, courage and resilience reminded me that it is not they who are HIV-positive but it is we who are all HIV-positive. In this article I would like to reflect on the cultural context of HIV/AIDS in India, its prevalence and the Church's response to this epidemic.
\end{abstract}

\section{INTRODUCTION}

A student recounted to me what had happened in his family. His uncle $(\mathrm{X})$, a pastor, suddenly developed a friendship with a young woman (Y) who approached him often at his home and began attending his church. The pastor never disclosed the name of the lady nor the reason for her conversing with him. This silence aggravated his wife, causing regular arguments between them. As conversation between $\mathrm{X}$ and $\mathrm{Y}$ steadily increased, so too did the distance between $X$ and his wife, resulting in $X$ 's wife ultimately filing for divorce. During this same period of time $\mathrm{Y}$ became ill and her visits stopped; instead, $X$ started to visit her but after some months she passed away.

$X$ conducted the service and secured a placement in the college with a substantial scholarship for the daughter of the deceased. Once the girl was settled in the college, $X$ called his immediate family members and a number of the trustworthy leaders from the church and broke his silence. He revealed that $Y$ was living with HIVIAIDS and was already in the last stages of her life, regularly coming for counselling. Being true to his calling as a pastoral counsellor, he kept confidentiality for fear that $Y$ would be

Prof. Nalini Arles, United Theological College, Bangalore, India; visiting lecturer, Dept Missiology, University of the Free State. E-mail: arles.nalini@ gmail.com.

Acta Theologica

2012 Suppl 16: 126-147

DOI: http://dx.doi.org/10.4314/actat.v32i1S.8

ISSN 1015-8758

(C) UVIUFS

<http://www.uovs.ac.za/ActaTheologica> 
stigmatised and discriminated by the members of the church, unable to worship God.

Had he disclosed that she was HIV-positive, he would also have been suspected as being the culprit and, by extension, her having passed away would make his own position more questionable and prevent her from dying with dignity. In a caste-ridden society, where discrimination regarding purity and pollution causes a clear divide between people, the culturally driven moralistic attitude of the Christians would have condemned her as a sinner. Local churches were already treating HIV/AIDS survivors with contempt, stating that they deserved to die as punishment from God. How then could he have disclosed the woman's story?

Having approached this context through a case study which enables us to delve into the context in India and the attitude of many members of the church, let us now examine the factual historical, cultural and religious factors concerning this highly polemical subject.

\section{INDIA AT A GLANCE}

HIV and AIDS are taboo words in India. The infection is varyingly referred to as "positive disease", "gay disease", "modern plague", "skinny disease" or "slim disease" (Samraj, David \& Suneetha 2011:5). Others tend to categorise HIV/AIDS with other incurable diseases such as cancer or diabetes, and refer to it as a "killer disease". Clearly, the name they give to the illness is indicative of their attitude towards it (Samraj, David \& Suneetha 2011:5).

India stands second globally in population to China, with over 1.1 billion inhabitants. "Shining" with its achievements of past glory and its legacy of housing ancient religions of rich and complex cultures, languages and faiths, when struck with the HIV/AIDS epidemic, India was simply unable to accept the fact. The immediate defence was denial, and silence was maintained (Solomon \& Ganesh 2002:19). Unsurprisingly perhaps, since the very fabric of Hinduism is built on a caste system, hierarchical in nature, sanctioned by religion, rooted in a philosophy of purity and pollution. This belief system has already discriminated against several millions in the past, denying their existence in society.

\subsection{Recognition of HIV/AIDS in India}

The first word uttered about HIV/AIDS was in 1980, and in 1982 Bombay first spoke of HIV/AIDS. In 1986 the virus was discovered in Chennai (Madras) where a doctor, Sunita Solomon, claimed to be the founder of the virus and established YR Gaitonde Centre (YRG) in 1993 for AIDS research 
and education. The centre also provides prevention, care, treatment and support services to people living with HIV/AIDS and their families (Solomon \& Ganesh 2002:19). Various sources give diverse figures of HIV/AIDSinfected people ranging from 20 to 25 million (Narain 2004:24). In 2007 Jai Narian (2004:26) predicted that 4.58 million were sufferers of HIV. The adult HIV prevalence stands at $0.36 \%$ and the majority of HIV infections occurs in men aged 15 to 44 years. It is estimated that some 70000 children below the age of 15 are infected with HIV and that 21000 children are infected every year through mother-to-child transmission (NACO - The National AIDS Control Organization (NACO) 2007). The country has an increasing population of children living with HIV, many of whom having lost either one or both parents to AIDS-related infections (NACO Report 2009-2010).

After years of denial the Government of India finally had to face the HIV/ AIDS epidemic and set up a National AIDS Committee under the Union Ministry of Health and Family Welfare in 1986. The committee's objective was

... to lead and catalyze an expanded response to the HIVIAIDS epidemic in order to contain the spread of the infection, reduce people's vulnerability to HIV, promote community- and familybased care to people with HIV/AIDS within an enabling environment without any stigmatization and discrimination, and alleviate the epidemic's devastating social and economic impact (Solomon \& Ganesh 2002:20).

In 1992 NACO was established to be supervised by the National AIDS Committee. In the same year, the government launched the National AIDS Control Programme (NACP) for HIV prevention. This plan established the administrative and technical basis for programme management and set up State AIDS Control Societies (SACS) in 25 states and 7 union territories. It was able to make a number of important improvements in HIV prevention such as improving blood safety, introducing Antiretroviral Therapy (ART), and raising awareness (Solomon \& Ganesh 2002:20).

NACO commented on the existence of the HIV/AIDS epidemic in their brochure India Responds to AIDS with the statement "AIDS presents the most serious public health problem in India today" (Solomon \& Ganesh 2002:19). Through their surveillance system they presented a grim picture of the prevalence of HIV in various states and population groups, conducting surveys from IDUs, sexually transmitted disease (STD) clinics, antenatal clinics and other sites consisting both of government institutions and private hospital-based or independent clinical laboratories. Their prediction of the prevalence was debatable as it was not drawn from a 
national source that contained the results of HIV testing by government institutions but was based solely on the sentinel surveillance mechanism (Solomon \& Ganesh 2002:20).

\subsection{Prevalence of HIV/AIDS}

Sunithi Solomon states the following:

- High HIV prevalence states include Maharashtra, Tamil Nadu, Karnataka, Andhra Pradesh, Manipur and Nagaland, where the prevalence of HIV infection is $1 \%$ or higher in antenatal women.

- Moderate HIV prevalence states include Gujarat, Goa and Pondicherry, where the prevalence of HIV infection is $5 \%$ or higher among high-risk groups, but lower than $1 \%$ in antenatal women.

- Low HIV prevalence states include all remaining states, where the prevalence of HIV infection is lower than $5 \%$ in any of the high-risk groups and lower than $1 \%$ among antenatal women (Solomon \& Ganesh 2002:20).

\subsection{Variegated and multiple responses}

Various non-governmental organisations, churches and religious groups responded and are still responding to the epidemic by establishing care centres, raising awareness through media such as films, music and art, testing, counselling, advocacy and even the provision of respite care. These organisations include the YRG centre, the Freedom Foundation, and Christian organisations such as Christian Medical Organisation of India, Salvation Army, CSI Synod initiative, CNI Synod Board of Health Services, National Lutheran Health and Medical Board, United Lutheran Church Association, Mar Thoma Church, and Syrian Church initiatives (Longchar 2005; Samraj, David \& Suneetha 2011; WCC 1997). However, there is considerable variation as to how these organisations and the rest of India have responded to the virus.

\subsection{The HIV virus in India}

HIV is characterised by its "genetic diversity" and "hyper-variability", especially in the cell domain. Jean Louis Excler analyses the type prevalent in India and states

In India HIV-1 subtype C is predominant; this accounts for 472 of all HIV infections worldwide, followed by subtype $B$, subtype $A$ and subtype E. The subtypes identified in India are Subtype C - 91\%, 
Subtype A - 3\%, Subtype D, E - 3\% (Narain 2004:370; Osmanov, et al. 2000:184-190).

She further mentions that a vaccine used against a subtype may not or only partially be protective against another subtype (Narain 2004: 370371). The existence of a range of subtypes within the country makes it naturally both more difficult and more costly to treat the virus.

\subsection{Transmission of the HIV virus}

In India the transmission of the HIV virus has been attributed to the following key reasons:

- A large majority (84\%) of the infections were attributed to heterosexual transmission due to unprotected sex between husband and wife and between commercial sex workers and men/women (Messer 2004:178; NACO 2009-2010:13). This is contrary to the myth existing at that time that the transmission was due to homosexual relationships. They identified truckers, migrants, manual workers and multiple partners as potential causes of transmission.

- A lower number of transmissions were attributed to bisexual and homosexual persons as possible sources of infection for AIDS cases.

- Commercial sex workers, including transgender, gays and lesbians.

- Sharing of needles among injecting drug users.

- Worryingly, reports lack information on women and children, but recent studies have reported that the HIV infection rates are increasing among:

a. Monogamous women, through unprotected sex with infected spouses.

b. Young people and children via mother-to-child transmission.

c. Children are most vulnerable: the statistics reveal that 70000 children below the age of 15 are infected with HIV and that 21000 children are infected every year (Varma 2010:Ch.7).

\section{EMERGING ISSUES}

- Child-headed households: Homes with both HIV/AIDS-affected adults face tremendous challenges of exploitation as they are inadequately prepared to move into adult roles. National and state governments, through the National AIDS Control Programme, are planning to 
increase their commitment to care and support for children infected and affected by HIV and AIDS and their family members by expanding policy initiatives and committing greater resources (Varma 2010:Ca.7).

- The increase of orphaned children: Some children are still in institutional foster care or orphanages. Foster care has advantages and disadvantages, the latter most commonly when children are abused. It is encouraging to note that the community is offering to take care of these children, although adoption remains unpopular and difficult for Christians as they are not allowed by law to adopt. The India HIV/AIDS Alliance in collaboration with the Tata Institute of Social Science conducted a "situational analysis of child-headed households and community foster care in Tamil Nadu and Andhra Pradesh States" in 2006 to develop greater understanding of the problems, needs and challenges of children heading households and children in community foster care in India (Varma 2010:148-149).

- Child carers: An increasing number of children have taken the role of adults as with child-led households but are caring for ill parents while also managing siblings, finances and exposure to the challenges of discrimination and/or exploitation (NACO Report 2009-10).

- An increasing number of street and working children (NACO Report 2009-10).

\section{MOVING FORWARD}

NACP's National AIDS Control Programme Phase-III (2007-2012) has the overall goal of halting the epidemic in India over the next five years and is moving from raising awareness nationally to:

- Behaviour change;

- A more decentralised response, and

- Increasing involvement of NGOs and PLHA networks (Varma 2010:152153; NACO 2009-10:11).

In addition, NACP has placed highest priority on preventive efforts, seeking to integrate prevention with care, support and treatment by means of a threefold strategy:

- Preventing new infections among high-risk groups and the general population; 
- Strengthening the infrastructure, systems and human resources in prevention, care, support and treatment programmes at district, state and national levels, and

- Strengthening the nationwide Strategic Information Management System (Varma 2010:153; NACO 2009-10:ii, 1).

\subsection{Measures of success}

There are similarities in the intervention, prevention and post-intervention methods of both government and non-governmental organisations, but differences exist in the number of persons to whom the services are offered, in the administration of ART drugs as well as in hospice and institutional care (NACO 2009-10).

- Targeted intervention for high-risk group population: Approximately 1290 intervention projects were initiated under various State AIDS Control Societies (SACS) and a further 225 are managed by donor partners, providing prevention and care services that cover $53 \%$ of Female Sex Workers (FSW) and 74\% of Injecting Drug Users (IDU).

- Link Workers Scheme: This community-based intervention addresses HIV prevention and care needs of the rural community (Varma 2010:162; NACO 2009-10:17-19).

- Blood safety: Voluntary blood donation campaigns were initiated and access to safe blood was ensured through a network of 1.103 blood banks. 100000 units were collected as of 31 January, 2010.

- Integrated counselling and testing centres: The NACO report identified the successful implementation of counselling in several testing centres, highlighting the need to focus on the emotional and physical impact of the virus (NACO 2009-10).

- Management of sexually transmitted infections: 916 STI/RTI clinics for training, reference and research centres are designated at the district and government teaching hospitals. In addition, services were also expanded in some private sectors.

- Condom promotions, notably, a multimedia campaign in the NorthEast region of India in September 2009 targeting youth through music and sports in Manipur, Mizoram and Nagaland (Varma 2010:162; NACO 2009-10:20-22, 30-31; Ramamurthy 2003:31).

- Red ribbon clubs were promoted in colleges encouraging peer-to-peer messaging on HIV prevention. 
- Drop-in-centres, supported by NACO, were run by PLHA networks to promote positive living and to improve sufferers' quality of life.

- The Red Ribbon Express train (RRE), which claimed to be the world's largest mass mobilisation against HIV/AIDS, was inaugurated by Sonia Gandhi on 1 December 2009 on the occasion of World AIDS Day. Also present were the National Rural Health Mission, and chairpersons of both the UPA and the Rajiv Gandhi Foundation. During its year-long run to cover 152 stations in 22 states it offered HIV testing, treatment of STIs and general health check-ups. It also provided exhibition vans to disseminate information to rural areas. The project was successful in mobilising political leadership in the states, districts and panchayats (NACO 2009-10:22-26).

However, as mentioned earlier, discrepancies do exist in the degrees of education relating to transmission, discrimination and stigmatisation; advocacy regarding the right and freedom of HIV/AIDS sufferers to education and medical care, and the provision of national and international conferences on HIV/AIDS for clergy, lay people, theological students and youths.

\section{HIV VIRUS IN THE SOCIO-ECONOMIC CONTEXT}

Certain cultural and social factors are undeniably responsible for perpetuating the spread of infection.

\subsection{Cultural: The position of women}

a. Although there are significant changes in the treatment and lifestyle of women, limitations are still prevalent in many parts of India, cutting across all sections of society. In a patriarchal system women are considered second-class citizens, subordinate to men.

b. Women must remain faithful to their husbands even if their husbands have other women in their lives. (One infected lady told me that she considered her infection of HIV/AIDS a gift given by her husband and was never angry with him.)

c. Women are given into marriage either in their teens or as a child, even while child marriages are banned in India. 
d. Child abuse, a phenomenon which was hidden earlier, is now discussed openly and brought to the public by press and media without any inhibition.

e. The denial of any kind of examination or testing for women sex workers by the pimps to whom they are enslaved. The author noticed this attitude in Bombay on a field trip with United Theological College students working with prostitutes.

f. Illiteracy and semi-illiteracy among women keeps them ignorant of the epidemic.

g. The need for a male child to aid in women's salvation forces a woman to have sexual relations with a man, although he may be infected. The fear of discrimination and shame of losing one's family name and the fear of hindering marriage prospects for one's younger sisters causes the affected woman to remain silent about her infection.

h. Dowry is another major factor which directly or indirectly aids in the increase of infection. On occasion, infected men take dowry from the girl they intend to marry with no disclosure. This often happens because a man needs the money for the dowry of his own sisters. The author heard of a case where a man agreed to marry a girl and fixed the dowry; unfortunately, his friend had an accident and the situation demanded that he offer to donate blood. He then discovered that he was HIV-positive. Later he argued with friends and the counsellor that he had kept silent in order to ensure that the marriage would take place in order to acquire dowry money for his own sisters. The counsellor subsequently intervened and informed the girl's family; eventually the marriage was cancelled. Of course, there were other ethical issues regarding confidence which needed to be addressed in this case, but it is clear that this cultural phenomenon is also a factor in the discussion of how HIVIAIDS is addressed in India.

i. Arranged marriages where a girl agrees to marry a man of whom she has no knowledge. Although the family does its best to find out the character of the groom, inevitably the man's HIV infection is not revealed until after the wedding. One encouraging recent advancement, however, was reported in the Deccan Herald newspaper, namely the "Right of Information" law. This legislation entitles women to seek disclosure of information on their prospective husbands (Varma 2010:Ch.7).

j. Denial of husband's property: After losing her husband, a woman is denied any inheritance from her husband's family, as this is passed on to his brothers. 
k. Kinship endogamous marriages: Marriages are fixed at the time of birth. The predicted couples such as uncles and nieces are not only given freedom to have sexual relations but are constantly spoken of as couples. The families simultaneously curtail the young girl's freedom by not allowing her to have casual conversation with her male colleagues, classmates, neighbours, and friends. The girl is bound to marry the person nominated by her family.

I. A girl's virginity is most revered and connected to family honour. The family's honour is at stake if she is found to have had pre-marital sex. In addition, she loses all marriage prospects.

It is clear, in such a patriarchal society where women are so flagrantly oppressed and regarded as subordinate to men, that where attempts to educate the populace have been made, these are frequently thwarted or made redundant by the existence of inflexible social norms.

\subsection{Myths}

Unsurprisingly, there remain a number of alarming myths in the common consciousness of India regarding the HIV virus, namely that

- Mental illness will be cured through marriage;

- Sexually transmitted diseases will be healed by having sex with a virgin;

- Double standard morality: It is often believed that men have more needs and it is obligatory for such needs to be met, so widowers of any age are allowed to marry young girls. Meanwhile, the remarriage of a widow is often frowned upon.

- A strong belief in prevention of HIV by methods such as diaphragms, cervical caps, sponges, spermicides, depo provera injections and contraceptive pills, and

- Cure is possible through native treatment such as "ayurvedic" or "homeopathic" medicines (native medicines also accepted by many educated people) which are often advertised in newspapers.

\subsection{Poverty}

Poverty certainly has created conditions ripe for HIV transmission:

a. Migration: Industrialisation and now globalisation have, on the one hand, improved economic growth by enhancing technology, communication, 
travel and information. On the other, it encourages migration which is a strong force in the splitting of families, as many spouses work in two different states or even foreign countries. Arguably, this increases the potential for extramarital relations and, by extension in this context, transmission (Varma 2010:Ch.7; Ramamurthy 2003:224, 246-248, 253-257).

b. Economic growth has caused rapid urbanisation in India, with large urban slum populations composed of migrants, manual labourers, and child labourers.

c. Unemployment and poverty, mostly among women, has led to prostitution.

d. Lack of education on nutrition, stress reduction, exercise, counselling and emotional support, to improve quality of life. Where people are aware of nutrition they may not be able to afford such food. In addition, stigma and discrimination still surround counselling and emotional support, preventing HIV-positive persons from being perceived as people in need of help (Varma 2010:Ch.7; Ramamurthy 2003:224, 246248, 253-257).

\subsection{Issues facing PLHA}

a. In India, as elsewhere, AIDS is often regarded as "someone else's problem", as something that affects people living on the margins of society, whose lifestyles are considered immoral.

b. People living with HIV have faced violent attacks, been rejected by families, spouses and communities.

c. In schools, children with HIV often face educational prejudice. For example, in March 2011 it was reported that two children were dismissed from a school in Kerala, South-West India, because they were HIV-positive, causing many protests by parents and children to readmit them.

d. HIVIAIDS people are refused medical treatment and even, in some reported cases, denied their last rites before they die.

It can be observed, therefore, that prejudices affecting the lives of HIV/ AIDS sufferers exist not just in the minds of the Indian people but also in the very systems of the country itself. 


\section{BARRIERS TO TREATMENT}

Antiretroviral treatment is very expensive (D'Cruz 2003:3), this precluding successful control of the illness in the majority of cases, particularly in non-urban areas. A second-line Antiretroviral treatment was funded by NACO through the Government in 2008, in two centres in Mumbai and Chennai. However, coverage remains limited; of the 3000 who needed to be on second-line treatment, only approximately 970 were receiving it as of January 2010.

Second-line Antiretroviral (ARV) drugs, unlike first-line ARTs, are not produced on a large scale in India due to patent issues that control drug pricing. Therefore, they can be 10 times more expensive than first-line ARTs. (Ironically, India is a major provider of cheap generic copies of ARVs to countries worldwide). However, the large scale of India's epidemic, the diversity of its spread, and the country's lack of finances and resources continue to present barriers to India's antiretroviral treatment programme and there is, generally, a lack of provision of palliative care by the Indian Government for HIV patients (Narain 2004:304, 308, 371; NACO 2009-10).

\section{THE CHURCH OF SOUTH INDIA'S RESPONSE TO THE HIVIAIDS EPIDEMIC}

The author examines the Church of South India's response to various social issues in its formation days in order to evaluate its response to the present HIV/AIDS epidemic. The literature in the 1950 s and 1960s, such as Christian participation in nation building, Changing patterns of family in India, Training volunteer workers, Towards involvement, Renewal and advance, (Devanandan \& Thomas 1960; Wilfred Scopes 1955; Thangasamy 1972; Ranson 1948) constantly sought to bring an awareness of the rapid social, economic and psychological problems in pastoral situations and the society due to industrialisation such as the eroding of market values, the breaking of extended families into unit families, the problems of migrant workers, cross-cultural marriages or problems of the elderly, parenting, unwed mothers and divorced parents. These are reflected in the deliberations of the CSI Synod and other boards and committees. They also challenged the imported theologies and exposed the need for contextual theologies. Their suggestions fall into two categories, the Structuralists and the Reformers. 


\subsection{Structuralists}

Their proposal was to liberate the bishops and clergy from administrative work as ancillary functions took over pastoral functions. Both laity and clergy have written to redress the imbalance of administrative responsibilities taking precedence over pastoral functions of healing, guiding, sustaining and reconciling (John 1972:62-63; Bhandare 1974:1ff.). Pastors were being

... forced to function as a collector of a revenue district and often wear the garb of a bureaucrat dealing with appointment, promotions, transfers, admissions, tours and committee meetings of a mundane nature (Paul 1967:7).

The ancillary functions such as "running schools, leasing coconut topes and tamarind trees, collecting rent and keeping accounts" took precedence over pastoral functions and, as Paul noted, these were performed with great diligence.

What a travesty of the promises which he made at his ordination!
In all the twelve promises the presbyter is called upon to make at
his ordination, according to the Ordinal of our church, there is not a
single word about the things which the average pastor these days
thinks are his important duties (Joel 1972:14).

a. The various units and conferences contributed to understanding the mission of the church and broadening the concept of pastoral care, such as the Tambaram Conference of 1938, the Industrial Mission of 1959-1963, Christian Home Movement (CHM), an offshoot of NCC which later worked with CMAI and social hygiene work of the thirties. Although their emphasis varied, their concerns to address the problems caused by industrial revolution were similar (Philip 1978:73-93).

b. To split the large size of the diocese into smaller units (Joel 1972:14).

c. To think of alternative structures which had been experimented such as Ashrams, Industrial Mission and the Medico Pastoral Association (Paul 1972:90-99).

\subsection{Reformers}

a. To start service projects such as dispensaries, counselling centres to give premarital counselling, marriage guidance, parenting and budgeting, etc.

b. To start professional groups as support groups.

c. To start employment centres to give vocational guidance. 
d. To include emerging disciplines or subjects into the curriculum of theological education and to address issues from the socio-economic perspective such as church and society, the impact of industrialisation, psychotherapy, and counselling (Paul 1972:96ff., 108).

These led the church to rethink pastoral care and its functions.

\section{RESULT OF THE RECOMMENDATIONS}

a. A remarkable increase in the work of the ordained ministry in the secular settings such as chaplains in industries and hospitals.

b. Development of industrial mission and its impact on the church, theological education and society (Ranson 1948;Paul 1958; Nalini Arles 1993).

c. Specialised training for laity and clergy abroad and in India. (People were sent to Thailand and UK for industrial mission and family counselling).

d. The Senate of Serampore offered courses in Pastoral Counselling. UTC offered pastoral counselling in 1956, followed by Leonard Theological College offering Marriage and Family Counselling in 1963, integrating Psychotherapy, Secular Therapies, Sociology, Psychology and Counselling Techniques to help people with their problems. Later the Christian Counselling Centre was established in Vellore in 1970.

e. Various indigenous and contextual theologies were developed and taught at UTC and other colleges. Later Dalit Theology was developed.

f. Various Vernacular Theological Colleges were established in various states of India.

g. An increase of literature in various theological disciplines.

h. The development of counselling centres.

\subsection{The strength of the church}

a. There was a strong uncompromising lay voice or prophetic voice, sometimes lonely voices, speaking with courage and boldness and challenging the structures.

b. There was a strong link between theological colleges and churches impacting one another. 
c. The theological commission of the church was proactive, producing informative and theological documents.

d. Systematic theological themes were addressed in the synod. A significant proportion of the time was allotted to such discussions.

e. Even at the diocesan level sufficient time was given for reflection and discussion of issues.

\section{TODAYS - CHURCH MEMBERS' RESPONSE TO HIVIAIDS EPIDEMIC}

The overwhelmingly proactive response of Christians to the tsunami was lacking in the case of HIV/AIDS. Similarly, from as early as 1770, the early missionaries' efforts were also more proactive in attempting to alleviate poverty, eradicate illiteracy, and provide health care and other social reforms. However, such an enthusiastic response to counter HIV/AIDS is currently not visible. The response is similar to the wider nation's response and could be categorised as follows.

\subsection{Reactors}

This group's response is similar to that of those who were primarily so shocked and overwhelmed that they initially denied that the HIV virus ever existed. Later, confronted with the reality of the epidemic, they justified their moralistic attitude by making comparisons that they were perfect and that those living with AIDS were sinners. Labelling included accusing, judging, mud-slinging and isolating, thus giving room for stigmatisation and discrimination. In this process, they viewed the church as a homogeneous, sectarian and closed group. Their view was contrary to the Biblical understanding and to Martin Luther, who describes the church as both "communion of saints and community of sinners" (Messer 2004:22; Bonhoeffer 1963:86, 146, 147). Such reactionary groups, according to psychologists, tend to dominate others by using scriptures and erecting cultural barriers, alienating the HIV/AIDS person and others.

\subsection{Upholders of scripture}

Some re-affirmed the literal, traditional, narrow and conservative interpretation of the scriptures. Using scriptures and judging the affected people only reveals the taking of God's power of judgment. In this process, they even sidelined God's healing, reconciling and empowering ministry, thus changing both God's nature of love, concern and care to legalism 
- God's unconditional love to conditional love and "gospel of life" to "gospel of death".

\subsection{Builders of barriers}

They engage in building and strengthening the barriers. Rather than building bridges, they continue to alienate and isolate people. This kind of alienation and isolation is already rooted in the Indian psyche which not only discriminates "Dalits" (the lowest Indian caste) but also women. Messer's observation is accurate in that such alienation destroys the very essence of the church when the sole purpose of Christ is acceptance of others, "Koinonia" or the hallmark of true fellowship (Messer 2004:22).

\subsection{Heretics - "exclusivists"}

As a country hosting many religions which, for the most part, coexist harmoniously, India is nevertheless fraught with tensions and societal fractures. Religion promotes inclusivity but the paradox is that, although it appears to be inclusive and eclectic, at its roots it is in fact exclusive. Such inclusive nature is superficial, bringing a cosmetic change such as re-painting the furniture and re-arranging it in the same room, rather than attempting to make a structural change. In their attitude towards HIV/ AIDS, Christians are entirely exclusive, holding the truth like water in a container and standing by the sea of God's love. Messer aptly interprets the real meaning of inclusivity as a "way of being, living, working and worshipping together in mission." He further emphasises the importance of inclusiveness by quoting Emil Brunner's words: "inclusiveness is to the church as fire is to burning" (Messer 2004:21).

\subsection{Predictors of time}

Some view HIV/AIDS as "signs" and symbols indicating that an eschatological end is coming soon. They quote the scripture to affirm their belief that these are signs for the second coming of Jesus Christ.

\subsection{Assimilators and adopters}

This group fundamentally believes that people with AIDS are God's children who have equal rights and freedom and who are more accepting about how the infection has been contracted. Let us, optimistically, focus on the most inclusive of the groups mentioned. There are inevitably, within this group, variances of understanding which should be highlighted. 


\subsection{Doers of God's mission}

Mission is not purely concerned with conversion but also with liberating and empowering HIV/AIDS people. A number of churches have responded by forming organisations, establishing taskforces for HIV/AIDS, and designating qualified people or committees to help with intervention and prevention. However, they have not established rehabilitation centres and hospices, as some Catholic organisations have done.

\subsection{Dialoguers}

They dialogue both with HIV/AIDS persons and with anti-HIV/AIDS persons, attempting to develop their personal understanding of the infection by means of seminars, workshops and publications. In this process they attempt to get to know HIV/AIDS persons and their needs and strengthen those struggling to accept their infection. They are determined church members belonging to different denominations, who are proactive in walking with HIV/AIDS persons and helping others understand HIV/AIDS. They do not hesitate to participate in advocacy of any form.

\subsection{Jugglers}

They juggle between their personal convictions of unconditionally accepting HIV/AIDS people and yet struggle with Church authorities who refuse to accept HIV/AIDS persons. Some Christian counsellors, judges, lawyers, doctors and teachers fall into this category. Some devote their energy in convincing church authorities while others spend their energy in empowering the authorities to accept HIV/AIDS persons. Others aim to empower HIV/AIDS sufferers and assign little importance to legalists and fundamentalists.

\subsection{Sympathisers}

They pity HIV/AIDS persons and therefore are involved in helping, preventing, advocating and empowering HIV/AIDS persons. There are two subsets of people, those who go beyond "pitying" by helping others to understand HIV/AIDS people and those who concentrate primarily in caring for HIV/AIDS persons. Both groups are involved in charity.

\subsection{Hypocrites}

They cash in on HIV/AIDS people by writing, speaking, organising conferences and gathering funds, utilising them for other purposes. 


\subsection{Re-readers of the text}

They advocate and attempt the re-reading of the texts from the HIV/AIDS perspective. This attempt is often overshadowed by the need to accept them and what should be done for them.

\subsection{Speed freaks}

They hit and run; they involve themselves in time-limited projects and carry out their projects as long as funding lasts.

\subsection{Outside carers}

This group understands their mission as "centrifugal", going to people and helping them in their domain rather than bringing them to the Church.

\subsection{Armchair theologians}

They insist on theological correctness and spend time in articulating theology. The impoverishment of this group is that most of them neither have ever met and dialogued with HIV/AIDS persons nor are living with infected persons. Their theology concerns HIV/AIDS people as objects and never subjects of their theology. Some of these theologians are akin to a "bull in a china shop", not being sensitive to the needs of HIV/AIDS people, since they have no direct experience of them.

\subsection{Safe and silent players}

There are a number of potential factors in the church's reticence to truly address this issue:

a. Expecting a theology to guide them: It may be true that there needs to be such a theology. However, there are already many articles from Biblical and theological perspectives, and articles on Luke 10:29 (Who is my neighbour?), Mark.1:40-45; 2 Kings 3:1.

b. Wanting to reconcile: The dialectical tensions between the Biblical and the theological perspective.

c. Fear of contamination.

d. Their mission is to save souls: HIV/AIDS people are perceived as the greatest sinners or pagans to be saved. 
Collect these articles and approaches and formulate what is needed: a Theology of Hope, a Theology of Cross and a Theology of Life. Let us consider seriously the African bishop's daring and liberal statement that the Church needs a "Theology of condoms. If not the church will have a theology of coffins" (Messer 2004:22; Longchar 2005:53, 104, 109).

\section{A NEW APPROACH TO REVISIT THE UNDER- STANDING OF CHURCH AND ITS MISSION}

If the Church is to be successful in truly including, understanding and helping HIV/AIDS sufferers, the following approaches need to be embedded:

a. To rethink the essence, purpose and meaning of the church, whether it is a club limited to members or open to all. The church must truly be catholic, universal and ecumenical; Galatians 3:28 graphically captures the vision "neither Jew nor Greek, neither slave nor free, neither male nor female, all are one in Christ Jesus." The Church's discrimination of people of lower castes, women, or indeed any perceived marginalised group, from knowledge, positions, powers, appointments, promotions or even theological education, needs to be addressed in order to truly improve its potential to positively affect the lives of people living with HIV/AIDS.

b. To revise the liturgy of the church from the perspective of HIV/AIDS sufferers and never be merely content with one special liturgy prepared for the celebration of World AIDS Day.

c. Christian teachings should include in-depth discussion of topics of human sexuality, use of condoms, safe sex, abstinence, fidelity, sexual behaviour, lifestyle and ethics.

d. The church should invest in promoting treatment, use of related drugs, routine clinical approaches and relevant treatment guidelines.

e. The church should promote a change in people's attitudes toward HIV/ AIDS. HIV-infected persons continue to live in a secret world, hoping to shield themselves from the stigma, scorn, and discrimination of the members of their community by not speaking about their infection. To them, even government support of antiretroviral drugs would be of little relevance.

f. To avoid the duplication of work, network and negotiate with others in order to get better involved in prevention and intervention. 
The church in all its weakness addressed the need of its day moving from being "centripetal" to "centrifugal" in the understanding of its mission, providing education and care through institutions. At present we have preserved the institutions as solid endowment machines. Unfortunately, power, politics and court cases seem to affect the church and are apparent in elections where the services of police and legal people have been called upon, even for solemn services. In the midst of present contemporary needs, calamities and catastrophes should the church revise its mission by exploring a new paradigm shift in mission thinking? However, individual church members were working with NGOs or institutions in dealing with HIV/AIDS. On 2 July 2010 the executive committee of the Synod of the Church of South India approved a policy to stop the spread of HIV, so that every congregation will accept the affected and the infected and work for their well-being. Some of the concerns are

The CSI policy boldly recognises and accommodates the PLHA in its sphere of concern and ministry. The policy also helps the church to understand the enormity of the problem and the responsibility that goes with it ... The CSI policy will involve its Churches, Health Care and Educational Institutions along with its members in a Program of Action ... to address the challenges posed by the pandemic of HIV and AIDS (CSI 2010:12-13).

I do not prescribe a theology nor preach a sermon but conclude with two statements - life-giving statements as a response from my HIV/AIDS friends. When asked the question "What do you need from us?", HIV/AIDS persons replied, "Be a voice to the voiceless" (Longchar 2005:14). Or, as Bill Gates suggested:

India can either be the home of the world's largest and most devastating AIDS epidemic or, with the support of the rest of the world, it can become the best example of how this virus can be defeated (Messer 2004:13-14).

\section{BIBLIOGRAPHY}

ARLES, N.

1993. The understanding of pastoral care and counselling in the Church of South India: With special reference to the work of the Christian Counselling Centre, Vellore. Unpublished Ph.D. Thesis, University of Aberdeen: Scotland. 
BHANDARE, R.S.

1974. Liberate the bishops and the clergy from the bondage of administration. The North Churchman, IV:7, July.

CSI SYNOD

2010. Policy of HIV and AIDS: A faith response of the Church of South India to the pandemic of HIV and AIDS. Chennai: CSI Centre.

D'cruz, P.

2003. In sickness and in health: The family experiences of HIVIAIDS in India. Kolkata: Webimpressions Pvt. Ltd.

Devanandan, P.D. \&. Thomas, M.M.

1960. Changing patterns of family in India. Bangalore: CISRS.

Dixon, P.

2002. AIDS and you. Secunderabad: OM Authentic Media.

Gates, B.

2002. Slowing the spread of AIDS in India. New York Times.

JOEL, J. L.

1972. The Church of South India and its structure. South India Churchman, July.

JoHN, A.D.

1972. What is wrong with us? South India Churchman, September.

KaLichman, S.C.

1998. Understanding AIDS: Advances in research and treatment. U.S.A.: American Psychological Association.

KuRUVILLA, P.

2004. HIVIAIDS- A handbook for the church in India. New Delhi: ISPCK.

LONGCHAR, A.W.

2005. Health, healing and wholeness: Asian theological perspective on HIVI AIDS. Jorhat: Barkataki and Company Pty. Ltd.

Messer, D.E.

2004. Breaking the conspiracy of silence: Christian churches and the global AIDS crisis. U.S.A.: Fortress Press.

NACO

2009-2010. NACO Annual Report. Delhi: Department of AIDS, Central Ministry of Health and Family Welfare.

NARAIN, J.P.

2004. AIDS in Asia: The challenges ahead. New Delhi: Sage Publications India Pty. Ltd.

Osmonov, s., Patton, C., Walker, N., Schwardlander, P.B. \& Esparza, J. n.d. WHO-UNAIDS network for HIV... Journal of AIDS 29:2. 
Padmakar, Victor,V., Caszo, B. \& Ecka, L.P.

n.d. CCC Information: The history of the formation and development of Christian Counselling Centre, Vellore. Vellore: CCC.

PAUL, R.D.

1958. The first decade: An account of the Church of South India. Madras: CLS.

1972. Ecumenism in action: Church of South India - An assessment. Madras: CLS.

PHILIP, T.V.

1978. National Conference of Theological Teachers. Religion and Society, XXX, September.

Prabhakar, S. \& Nalunakkal, G.M. (eds)

2004. HIVIAIDS: A challenge to theological education. Bangalore: National Printing Press.

RAMAMURTHY, V.

2003. HIVIAIDS: Vulnerability in South Asia. Delhi: Authors Press.

RANSON, C.W.

1948. Renewal and advance. London: Edinburgh Publishing House.

Samraj, S., A. David, Lavanya \& Sujay Suneetha (eds)

2011. AIDS in India: Who cares anyway? Bangalore: Centre for Contemporary Christianity.

SCOPES, W.

1955. Training volunteer workers in the service of the Christian Church in India. Lucknow: Lucknow Publishing House.

Solomon, S. \& Ganesh, A.K.

2002. HIV in India. A Special Consultation Report 10:3, July-August.

VARMA, S.

2010. Gender: HIV and social work. New Delhi: Rawat Publications.

Wcc

1997. A WCC Study Document, Facing AIDS: The challenge, the churches' response. Switzerland: WCC Publications.

Keywords

HIV/AIDS

India

Church
Sleutelwoorde

HIV/VIGS

Indië

Kerk 